TITLE:

\title{
The protective role of Kupffer cells in humoral injury of xenoperfused rat livers(Abstract_要旨)
}

\author{
AUTHOR(S): \\ Takeyama, Osamu
}

\section{CITATION:}

Takeyama, Osamu. The protective role of Kupffer cells in humoral injury of xenoperfused rat livers. 京都大学, 2000, 博士(医学)

ISSUE DATE:

2000-03-23

URL:

http://hdl.handle.net/2433/180827

RIGHT: 


\begin{tabular}{|c|c|}
\hline 氏 & 筷 荒 \\
\hline 学位(専攻分野) & 博 士 （医 学） \\
\hline 学位記番号 & 医 博 第 2193 号 \\
\hline 学位授与の日付 & 平成 12 年 3 月 23 日 \\
\hline 学位授与の要件 & 学位規則第 4 条第 1 項該当 \\
\hline 研究科 - 専攻 & 医学研究科外科系専攻 \\
\hline 学位論文題目 & $\begin{array}{l}\text { The protective role of Kupffer cells in humoral injury of xenoperfused rat } \\
\text { livers }\end{array}$ \\
\hline
\end{tabular}

（異種灌流ラット肝の液性傷害における Kupffer 細胞の保護的役割）

論文調查委員 教授和田洋已 教授田中紘一 教 授 山岡義生

\section{論 文内容 $の$ 要 旨}

臟器移植のドナー不足を解決する手段の一つとして異種動物の臓器を移植に用いる研究が積極的に行われている。心臓や 腎臟の異種移植では, 異種反応性自然抗体（主にIgM）や補体などの液性因子によって移植後数分以内に超急性拒絶反応が 起こりグラフトの機能は廃絶する。一方, 肝臟ではこのような超急性拒絶反応は比較的起こりにくく，その機序については 未だ明かにされていない。本研究では肝臓における異種免度反応の特異性を解明する手がかりとして肝非実質細胞の一つで ある Kupffer 細胞に注目し，異種免疫反応における Kupffer 細胞の関与とその役割について検討した。

【実験 1】雄性 Wistar ラットに塩化ガドリニウム $\left(\mathrm{GdCl}_{3}\right)$ 溶液 $10 \mathrm{mg} / \mathrm{kg}$ を実験の 48 時間前と 24 時間前の 2 回静注し Kupffer 細胞の貪食能を抑制した。対照群には生理食塩水を静注した。これらのラットの肝蔵を摘出し, 閉鎖回路において ヒト新鮮血またはラット新鮮血で 180 分間灌流した。実験群は以下の 4 群とした。1 群：生理食塩水投与後異種（七ト）血 灌流 $(\mathrm{n}=8) ， 2$ 群： $\mathrm{GdCl}_{3}$ 投与後異種血灌流 $(\mathrm{n}=8) ， 3$ 群：生理食塩水投与後同種（ラット）血灌流 $(\mathrm{n}=5), 4$ 群: $\mathrm{GdCl}_{3}$ 投与後同種血灌流 $(\mathrm{n}=5)$ 。灌流液中の肝実質細胞冕脱醉素である ALT 值および灌流肝組織の hematoxylin-eosin （H-E）染色標本で組織傷害を評価し， 1 群と 2 群については灌流液中の TNF- $\alpha$ を測定し，その局在を免疫染色にて検討し た。

（結果）ALT は異種血で灌流した 1 群と 2 群で時間と共に上昇し，2 群の方が 1 群よりあ有意に高値を示した $(\mathrm{P}<0.05) 。$ $\mathrm{H}-\mathrm{E}$ 染色でも 1 群に比較して 2 群では小葉間出血, 壊死等の組織傷害が著明であった。TNF- $\alpha$ は 1 群と 2 群で有意差は無 く, 免疫染色では Kupffer 細胞以外に門脈・肝動脈内皮等にも陽性であった。同種血で灌流した 3 群と 4 群の ALTは 1 ・ 2 群に比較し有意に低值であり, また両群間に有意差は見られなかった。

【実験 2】異種反応に関与する抗体 (IgM) や補体 (C 3 ) と Kupffer 細胞との関係を調べるために, 実験 1 と同様に生理 食塩水（1 群）または $\mathrm{GdCl}_{3}$ ( 2 群) 前処置ラットの肝蔵より Kupffer 細胞を分離し培養した。2 4 時間後に10\%七ト血清入 りの培養液と交換して 60 分間培養し, Kupffer 細胞によるヒト C 3 及び IgM の取り込みについて蛍光抗体法で検討した。

（結果）1群では Kupffer 細胞の細胞質内にヒト C 3 の取り込みが認められたが，2 群では見られなかった。ヒトIgMに ついては両群間の明かな差は認められなかった。

【考察】肝虚血再灌流などの実験モデルでは, $\mathrm{GdCl}_{3}$ で Kupffer 細胞の貪食能を狮制すると TNF- $\alpha$ など Kupffer 細胞から の炎症性メディエーターの放出が抑制されて肝傷害が軽減される事が報告されている。しかし本研究の異種肝灌流モデルで は $\mathrm{GdCl}_{3}$ の投与で TNF- $\alpha$ は抑制されず，逆に肝傷害は增強した。TNF- $\alpha$ が免疫染色にて Kupffer 細胞以外に血管内皮細胞 等にも認められた事から, Kupffer 細胞由来の TNF- $\alpha$ の関与は相対的に少ないものと考えられた。超急性拒絶反応は, 自然 抗体が血管内皮細胞上の異種抗原に結合し補体が活性化する事によって内皮細胞や実質細胞傷害を生じる液性傷害である。 しかし実験 2 で示すように Kupffer 細胞には異種の C 3 に対する貪食作用があり， $\mathrm{GdCl}_{3}$ によってこの作用は抑制された。 
従って肝蔵の異種反応ではこの Kupffer 細胞の貪食作用によって補体の活性化が㧕制されており, $\mathrm{GdCl}_{3}$ で Kupffer 細胞 を抑制すると補体の活性化が進み液性傷害が増強するものと考えられた。

【結論】Kupffer 細胞には異種反応から肝臓を保護する作用があり，その機序の一つとして異種の補体を取り込む作用が関 与している事が示唆された。

\section{論 文審查の結果の要旨}

異種動物の臓器をヒトの移植に用いるためには, 異種蔵器に対する拒絶反応の機序を解明し克服する事が重要である。本 申請者は肝臟の非実質細胞の一つである Kupffer 細胞の異種免疫反応における役割を明らかにすることを目的として, ラッ トの肝臟をヒト血液で灌流する異種灌流モデルにおいて Kupffer 細胞の機能を選択的に抑制する塩化ガドリニウム $\left(\mathrm{GdCl}_{3}\right)$ を用い, $\mathrm{GdCl}_{3}$ 投与群と非投与群における超急性拒絶反沁の傷害を比較した。その結果, $\mathrm{GdCl}_{3}$ で Kupffer 細胞を 抑制した方が肝傷害が増強することを明らかにした。また， $\mathrm{Gdcl}_{3}$ 投与及び非投与ラットより分離培養した Kupfer 細胞を 用いた実験において，Kupffer 細胞は異種血清中の補体成分 (C 3) に対する貪食作用を持ち， $\mathrm{GdCl}_{3}$ によってこの作用は抑 制される事を示した。即ち, Kupffer 細胞は異種の補体成分に対する貪食作用によって補体の活性化を抑制し，肝臓を超急 性拒絶反応における液性傷害から防御する働きを持っている事を示した。

以上の研究は，これまでほとんど知られていなかったKupffer 細胞の異種免疫反応における役割を明らかにした点に意義 があり,これによって肝蔵における異種免疫反応の機序の解明に貢献し, 肝移植のドナー不足を解決する手段としての異種 肝移植の研究発展に寄与するところが多い。

したがって, 本論文は博士 (医学) の学位論文として価値あるものと認める。

なお，本学位授与申請者は，平成 12 年 1 月 19 日実施の論文内容とそれに関連した試問を受け，合格と認められたもので ある。 